American Journal of Environmental Sciences 7 (4): 362-369, 2011

ISSN 1553-345X

C) 2011 Science Publications

\title{
Relationship to the River: The Case of the Muar River Community
}

\author{
${ }^{1}$ Bahaman Abu Samah, ${ }^{1}$ Sulaiman Md. Yassin, \\ ${ }^{1}$ Hayrol Azril Mohamed Shaffril, \\ ${ }^{1}$ Md. Salleh Hassan, ${ }^{2}$ Mohd Shahwahid Othman, \\ ${ }^{3}$ Asnarulkhadi Abu Samah and ${ }^{1}$ Siti Aisyah Ramli \\ ${ }^{1}$ Laboratory of Sustainable Development and Agriculture Extension, \\ Institute for Social Science Studies, University Putra Malaysia, \\ Putra Infoport, 43400 Serdang, Selangor Darul Ehsan, Malaysia \\ ${ }^{2}$ Department of Hospitality and Recreation, Faculty of \\ Economy and Management, Universiti Putra Malaysia \\ ${ }^{3}$ Department of Social and Development Science, \\ Faculty of Human Ecology, \\ Universiti Putra Malaysia, Malaysia
}

\begin{abstract}
Problem statement: Muar River which located in Johor, is an important river in Malaysia. Previously Muar River had a huge influence on the socio-economic status of the community. It has been used as the sources of income, protein and as well as the major mode of transportation for the community and traders. However, does the Muar River still has that influences on this modern day? The answer of this pertinent question will fulfill the main objective of this study which is to discover Muar River relationship with its surrounding community. Approach: In addition to relationship with the river, this quantitative study was conducted to determine the Muar River community agreement towards initiative to develop the river. A total of 300 respondents from 19 villages along Muar River were selected based on the simple random sampling. Results: Based on the analysis of the results, it can be concluded that Muar River still has a lot to offer to its surrounding community especially for the recreational activities (fish and prawn fishing). A large majority of Muar River community have a moderate and high level of agreement towards the river development. Further analysis performed revealed that income per month, number of household, age, distance to Muar River and period of staying in the areas had significant relationships with agreement towards river development. Conclusion/Recommendations: It is recommended that additional recreational facilities can be added, events at national and international level especially on fish and prawn fishing can be held at Muar River and campaign on the importance of river development and the danger of river pollution can be conducted.
\end{abstract}

Key words: River development, socio-economic activities, muar river community, community development

\section{INTRODUCTION}

Muar river: Muar River is one of the major rivers in Malaysia. Besides the fact that the Pahang River is the longest river in Peninsular Malaysia, the significant roles played by the Muar River in enhancing the socioeconomic status of Muar River community cannot be denied. Muar River starts from a place called "Jambu Lapan" in Jempol, Negeri Sembilan and flows to Malacca straits at Kuala Muar, in Johor. Muar River is famous with its fresh river prawn. There are two bridges in Muar town that cross the Muar River. The first one, known as Sultan Ismail Bridge was constructed in 1967 as an alternative for ferry service

Corresponding Author: Bahaman Abu Samah, Laboratory of Sustainable Development and Agriculture Extension, Institute for Social Science Studies, University Putra Malaysia, Putra Infoport, 43400 Serdang, Selangor Darul Ehsan, Malaysia 
and 38 years later, in 2005 the second bridge was built. Among the main attraction of this river such are Tanjung Emas Park, Tanjung Emas Jetty and Muar Town Park, which is located at the estuary of Muar River and the bombed bridge during the World War 2 or locally known as "Jambatan Patah". Furthermore, there are two Sultan Ibrahim mosques; the new one is situated in Muar Town while the older one is constructed at the northern bank of the Muar River at Tanjung Agas. There is another interesting place called Biawak Busuk, the place where Parameswara, the first king of Malacca transited before he went to Malacca to build his empire. Of course, not too forget, the famous historical police station of a place called Bukit Kepong, a place where 22 police officers defended their police station from 180 communist terrorists. Muar River is also related with famous legendary Malay warrior called "Hang Tuah", Muar River was the route used by Hang Tuah to bring beautiful princess called "Tun Teja" to Malacca. In the old days, people from Pahang used Muar River as one of their main routes to Malacca, besides, Muar River was also the main route used by traders to go to Terengganu or Kelantan, two states located in the east of Peninsular Malaysia. Facts stated above have revealed that in the previous days the communities were highly dependent to Muar River for their socio-economic activities; nevertheless can the scenario still be seen in these modern days? The answer of this question will bring us to the main question of this study which is to investigate Muar River community relationship with Muar River.

Potential Socio-economic benefits that can be gained from the river development: Social development: From a social perspective, the impact of the river development is hard to be quantified in monetary terms. Nevertheless, it still have a great impact on the community social development. The communities in Negeri Sembilan and Johor, the two states through which Muar River flows like many other states in Malaysia have the opportunity to improve their social activities. River development can strengthen community and family relationship through social activities such as picnic, fishing, kayaking/canoeing and other activities. On top of it, the rivers can educate the children who learn to play and relate life to the rivers. Undoubtedly the river development will provide the powerful force to attach this community together, to add value to the community through a cross border project (for example, inland waterway) and inculcate a great sense of civic pride in this area. Doubtlessly, this can be catalyst in realizing the mission of "One Malaysia", an idea raised by current Malaysia Prime Minister in his effort to unite Malaysians. This 'feel good factor' is something which is impossible to measure but do have greater reward for the community to which it applies (McCartan and Brady, 2007).

Increase income of the community: River can be seen as the foundation of prosperity and economic growth. Potential industries such as tourism, recreational activities, boat making industry, fish net rearing, boat rent industry and agriculture industry are among the industries that can be developed along the river. All of these will drive towards rural development which has the capacity of generating economic activities and promote social development and cohesion. River especially those which have been declared as the tourism areas has a huge potential for local economic growth. Along Muar River for example, there are a number of historical places that have a lot of potential to be further developed. The famous police station of Bukit Kepong, the British bombed bridge during World War 2 at Buloh Kasap, Sultan Ibrahim Mosques and the Tun Teja tomb for examples should be freshen back in the memory of Malaysian. Recreational activities such as fishing and kayaking are among the potential activities to be further developed. Through these recreational activities such as fish and prawn fishing, boat renting, tourism, restaurants and hotel for examples can generate additional income for Muar River community. Their catches, besides they use it as their sources of protein; they can sell it to get some additional income. Fresh prawn in Muar River for example, can reach the price of Ringgit Malaysia 35 per kilo (approximately USD 11 per kilo).

Rural development through economy development opportunity: River development can be an effective source for bulk commodities and agricultural activities. Agriculture as we know has been long linked with poverty alleviation (Bahaman et al., 2010; Shaffril et al., 2010; Hassan et al., 2010). In some areas especially the rural area, river development are absolutely required for the continued of economic health of many remote areas (Yassin et al., 2010). Rural development will provide opportunities for some undeveloped and left behind areas that are in need of major improvement and these areas will have their chances to be exposed to the development. It will create the business opportunities for rural enterprise development that are lacking in the area. This is essential especially in an area where a declining agricultural base needs to be suppported by 
the diversification of economic activities. Shops, shopping malls and groceries for example can be established. Apart of this, boat making industry, fish net rearing, boat rent industry, agriculture and tourism are among the industries that shall prosper. Doubtlessly, rural development opportunities will promote social development and cohesion. This is vital especially in an area where communities have been separated by the border. Moreover, river development can be one of the tools to build a strong community and drive them towards their full potential. If such development occur, it will attract people to come and live in these areas, thereby building and consolidating local communities on a long term basis.

As the source of protein: Rivers should be protected from disastrous human activities and environmental changes due to the sources that it has (Shaffril et al., 2011; Hossain et al., 2011; Yamani et al., 2011). Muar River offers plentiful sources of protein. Famous with its fresh prawn and some species of fishes, Muar River community can depend on it and other sources of the river system for some of their protein in their diets. Even though the quantity is reduced due to the rapid development of commodity plantation along the Muar River, it is still enough for the needs of Muar River community. By having this they can save some of their expenditure on food.

Alternative transportation: River can act as an alternative transportation for the community (Misra, 2007; Sudar, 2005) and doubtlessly Muar River also have the potential. One of the posible transportation developments that can be brought to Muar River is the Inland waterway system. Inland waterways can be a mechanism to create a sustainable mobility of goods and people (Misra, 2007). Having this means that there are alternatives transportation for community especially those on urban areas for going back to their village during the festive season such as "Hari Raya", Chinese New Year" and "Deepavali" which are crucial. Certainly, by having this type of alternative transportation, it will provide aid in improving the economic well-being, psychological well-being, social well-being and health well-being of the local community. In the early 1930-1950, it can be noted that Muar River has been used for transporting palm. Moreover, there was also a ferry service during 1950s that transporting people from Bukit Kepong to Singapore; if previously all of these can be done, why not on this day?
Enhancing quality of life: All of the potential socioeconomic effects brought by the river development have influence on the level of quality of life of the community (Yassin et al., 2011). Without doubt river has a huge potential to bring sustainable economy benefits to local businesses and communities at large. This is about enhancing the objectives well-being of the communities. On top of it, rivers can play a role in supporting sustainable transport in urban and rural areas. In addition, their diversity, beauty, history and natural environment contribute to the health and the subjective well-being of individuals and society. The surroundings with which they interacts daily, greenery, open spaces and the wider environment, a totality of which the rivers are an important component, are part of their own heritage, contributing to their individual and collective quality of life. In short, both the subjective well-being and objective well-being of the communities in the affected area could be enhanced and improved.

\section{MATERIALS AND METHODS}

Based on the simple random sampling employed, a total of 300 villagers from 19 villages along Muar River have been selected for this study. Instrument used for this study was a questionnaire that was pre tested earlier in the two selected villages. The pre test has resulted in the Cronbach Alpha value of .885 thus exceeding the threshold of 0.70 recommended by Nunally (1967), indicating that the instrument used for this study was reliable. Survey was conducted to get the data needed. For the question regarding relationship to the river, close ended questions were asked and the respondents were given an option of "yes" or "no" for each question asked. For the questions related to their agreement towards river development, the respondents were given an option of a 5-point likert like scale. To fulfill the objectives determined, SPSS software was used where descriptive and inferential analyses were performed. Descriptive and inferential statistics were employed to run the appropriate analyses.

\section{RESULTS}

Summary of socio-demographic profile of the study respondents is presented in Table 1 . As depicted from Table 1, majority of the respondents aged more than 50 years $(62.3 \%)$. Comparatively a total of $33.7 \%$ of the respondents earn between RM751-RM1,500 a month and $19.7 \%$ of the respondents earned more than RM2,501 a month. It is interesting to note that almost half of the respondents (49.3\%) have stayed in the area for more than 45 years. Majority of the respondents 
(57.0\%) stayed $<10$ kilometer away from the nearest city compared to $43.0 \%$ of the respondents who stayed $>11$ kilometer from the nearest city. More than three quarters of the respondents $(76.0 \%)$ stayed $<1 \mathrm{~km}$ from the Muar River while less than a quarter of the respondents $(24.0 \%)$ stayed $>1 \mathrm{~km}$ from the Muar River.

As depicted in Table 2, about two thirds of the respondents were male $(69.0 \%)$. Slightly more than one third of the respondents $(34.7 \%)$ had a primary school level of education had no schooling. On the contrary, only $2.7 \%$ of the respondents received Degree/Master/PhD. In relation to questions related to their health, a large majority of the respondents $(71.3 \%)$ reiterated that their job did not require them to do physical activities. About two third of the respondents $(65.8 \%)$ practice exercise for two times or less in a week. Interestingly, a large majority of the respondents $(84.0 \%)$ had gone for annual medical checkups.

Relationship with muar river: Table 3 presents three information related to the relationship with Muar River namely (1) daily usage; (2) recreational activities and (3) sources of income

Daily usage of the river: With respects to daily usage of river, only a small percentage of the respondents still use the river for their daily needs. A total of $14.7 \%$ still use the river for taking bath, another $11.7 \%$ of the respondents still use the river for washing and $15.7 \%$ of the respondents still use the river for their plantation and animals rearing activities. This small percentage that still use the river for their daily needs is not surprising as a huge number of government projects related to the rural communities basic needs have been implemented. It is a positive indicator that the impact of such rural projects can be seen on the Muar River community.

Recreational activities: In term of recreation activities, a total of five related activities namely (1) fishing (anglers) activities; (2) netting activities; (3) spending leisure time with family; (4) kayaking/canoeing and (5) picnic activities. Data presented in Table 3 unveil that a large number of the respondents still use the river for their recreation activities especially activities that are related to fish and river prawn catching. Almost half of the respondents $(48.7 \%)$ still use the river for the purpose of fishing (angler), more than one third of the respondents $(36.0 \%)$ still use the river for netting activities, a quarter of the respondents $(25.0 \%)$ still use the river to spend leisure time with their family, $11.7 \%$ of the respondents still use the river for kayaking/canoeing and $13.7 \%$ still use the river for picnic activities.
Table 1: Socio-demographic profile of the respondents $(n=300)$

\begin{tabular}{|c|c|c|c|c|}
\hline Factor & Frequency & Percentage & Mean & S.D \\
\hline \multicolumn{3}{|l|}{ Age (years) } & 54.20 & 13.20 \\
\hline & 41 & 13.7 & & \\
\hline$\overline{4} 1-50$ & 72 & 24.0 & & \\
\hline $51-60$ & 95 & 31.7 & & \\
\hline $61-70$ & 62 & 20.6 & & \\
\hline$>70$ & 30 & 10.0 & & \\
\hline \multicolumn{3}{|c|}{ Income per month(ringgit Malaysia) } & 2060.58 & 2887.0 \\
\hline$\leq 750$ & 73 & 24.3 & & \\
\hline$\overline{7} 51-1500$ & 101 & 33.7 & & \\
\hline $1501-2500$ & 67 & 22.3 & & \\
\hline$>2501$ & & & 59.00 & 19.70 \\
\hline \multicolumn{5}{|c|}{$\operatorname{Min}=100$} \\
\hline \multicolumn{3}{|c|}{ Period of staying in the areas (years) } & 40.59 & 21.55 \\
\hline$\leq 15$ & 54 & 18.0 & & \\
\hline$\overline{16} 6-30$ & 50 & 16.7 & & \\
\hline $31-45$ & 48 & 16.0 & & \\
\hline $46-60$ & 90 & 30.0 & & \\
\hline$>60$ & 58 & 19.3 & & \\
\hline \multicolumn{3}{|c|}{ Distance to the nearest city $(\mathrm{km})$} & 13.62 & 13.04 \\
\hline$<10$ & 171 & 57.0 & & \\
\hline & 129 & 43.0 & & \\
\hline \multicolumn{3}{|c|}{ Distance to muar river $(\mathrm{km})$} & 1.44 & 3.01 \\
\hline$\leq 1$ & 228 & 76.0 & & \\
\hline$>1$ & 72 & 24.0 & & \\
\hline
\end{tabular}

\begin{tabular}{lcc}
\multicolumn{3}{l}{ Table 2: Socio-demographic data of the respondents $(\mathrm{n}=300)$} \\
\hline Gender & Frequency & $(\%)$ \\
\hline Male & 203 & 69.0 \\
Female & 97 & 31.0 \\
Level of education & & \\
Never gone to school & 19 & 6.3 \\
Primary school & 104 & 34.7 \\
PMR/SRP/LCE & 77 & 25.7 \\
SPM/SPMV/MCE & 75 & 25.0 \\
Skills certificate & 7 & 2.3 \\
STPM/Diploma & 10 & 3.3 \\
Degree/Master/PhD & 8 & 2.7 \\
Nature of job require physical activities & & \\
Yes & 86 & 28.7 \\
No & 214 & 71.3 \\
Number of exercise done in a week & & \\
$\leq 2$ times & 197 & 65.8 \\
2-3 times & 44 & 14.7 \\
$\geq 5$ times & 59 & 19.7 \\
Go for annual medical check up & & \\
Yes & 252 & 84.0 \\
No & 48 & 16.0 \\
\hline
\end{tabular}

Table 3: Relationship to the river $(\mathrm{n}=300)$

\begin{tabular}{lc}
\hline Relationship to the river & Yes (\%) \\
\hline Daily usage & \\
Taking bath & 14.7 \\
Washing & 11.7 \\
Farming and animal rearing activities & 15.7 \\
Recreation activities & \\
Fishing (anglers) & 48.7 \\
Netting & 36.0 \\
Leisure time with their family & 25.0 \\
Kayaking/canoeing & 11.7 \\
Picnic & 13.7 \\
Sources of income & \\
Fish fishing & 12.3 \\
Prawn fishing & 10.7 \\
Boat renting & 6.3 \\
Fish cage rearing & 1.7 \\
Prawn cage rearing & 1.0 \\
\hline
\end{tabular}


Am. J. Environ. Sci., 7 (4): 362-369, 2011

Table 4: Statements measuring agreement towards river development

\begin{tabular}{|c|c|c|c|c|c|c|}
\hline Statement & 1 & 2 & 3 & 4 & 5 & Mean \\
\hline Development of the river will promote local development growth & - & 1.3 & 11.3 & 59.3 & 28.0 & 4.14 \\
\hline Development of the river will benefit the local community & - & 2.3 & 10.0 & 59.7 & 28.0 & 4.13 \\
\hline Development of new towns along the river is a viable business & - & 2.0 & 12.3 & 58.7 & 27.0 & 4.10 \\
\hline $\begin{array}{l}\text { By creating a recreation area will be able to promote closer ties between } \\
\text { families and local communities }\end{array}$ & - & 1.7 & 13.3 & 60.7 & 24.3 & 4.08 \\
\hline The development of the river will enhance local community awareness towards the river & - & - & 1.7 & 13.7 & 63.3 & 4.04 \\
\hline Development of the river transport system is a good system to the existing transportation system & 0.3 & 7.3 & 13.0 & 58.0 & 21.3 & 3.93 \\
\hline Efforts to develop the river will be able to beautify the river environment & 0.7 & 4.7 & 13.0 & 64.7 & 17.0 & 3.93 \\
\hline River development will reduce the flood risks & 1.7 & 5.7 & 25.7 & 52.7 & 14.3 & 3.72 \\
\hline Development of the river will negatively affect the activities of fish and prawn fishing & 3.3 & 22.0 & 25.3 & 41.7 & 7.7 & 3.28 \\
\hline Development of the river will negatively affect the flora and fauna of the river & 3.0 & 20.3 & 30.0 & 40.3 & 6.3 & 3.26 \\
\hline $\begin{array}{l}\text { Development of the river will affect the sources of income of the local communities } \\
\text { based on the recreational activities }\end{array}$ & 7.7 & 24.7 & 25.3 & 36.0 & 6.3 & 3.09 \\
\hline Efforts to develop the river will cause environmental pollution & 4.0 & 25.7 & 31.7 & 32.3 & 6.3 & 3.11 \\
\hline
\end{tabular}

Table 5: Overall level of agreement towards river development

\begin{tabular}{lllll}
\hline Level & Frequency & Percentage & Mean & S.D \\
\hline $\begin{array}{l}\text { Agreement towards } \\
\text { river development }\end{array}$ & & & 3.61 & 0.459 \\
Low (1-2.33) & 1 & 0.3 & & \\
Moderate (2.34-3.66) & 184 & 61.3 & & \\
High (3.67-5.00) & 115 & 38.4 & & \\
\hline
\end{tabular}

Table 6: Difference in agreement towards river development for selected independent variables using Independent t-test

\begin{tabular}{lrrrlll}
\hline Variables & $\mathrm{n}$ & Mean & $\mathrm{SD}$ & $\mathrm{t}$ & $\mathrm{p}$ & $\mathrm{d}$ \\
\hline Gender & & & & 1.232 & 0.219 & 0.152 \\
Male & 207 & 3.63 & 0.473 & & & \\
Female & 93 & 3.56 & 0.428 & & & \\
\hline
\end{tabular}

Sources of income: For the purpose of relationship to the river in term of sources of income, a total of five income related activities were asked to the respondents which include (1)fish fishing; (2) prawn fishing; (3) fish cage rearing; (4) prawn cage rearing and (5) boat renting. Results reveal that only a small percentage of the respondents still use the river as their sources of income as only $12.3 \%$ involved in fish fishing, $10.7 \%$ still involved in prawn fishing and $6.3 \%$ involved in boat renting activities. An additional $1.7 \%$ and $1.0 \%$ involved in fish cage rearing and river prawn cage rearing, respectively.

Agreement towards River development: Respondents were asked on their perception towards the river development. For this purpose a total of 12 statements related to river development were used. For each of the questions the respondents were given an option a 5- point likert-like scale $(1=$ strongly disagree, $2=$ disagree, $3=$ moderately agree, $4=$ agree, $5=$ strongly agree).

Data presented in Table 4 have revealed that a total of eight statements have recorded a high level of agreement (3.67-5.00) and the statements were (1) Development of the river will promote local growth (M = 4.14); (2) Development of the river will benefit the local community $(\mathrm{M}=4.13)$; (3) Development of the new towns along the river is a viable business $(\mathrm{M}=$
4.10); (4) By creating a recreation area will be able to promote closer ties between families and local communities $(\mathrm{M}=4.08)$; (5) The development of the river will enhance local community awareness towards the river $(\mathrm{M}=4.04)$; (6) Development of the river transport system is a good system to the existing transportation system ( $\mathrm{M}=3.93)$; (7) Efforts to develop the river will be able to beautify the river environment $(\mathrm{M}=3.93)$ and (8) River development will reduce the flood risks ( $\mathrm{M}=3.72)$.

Agreement towards river development was computed using the mean summated score of the 12 statements. The scores were categorized into three levels namely low, moderate and high for scores between 1-2.33, $2.34-3.66$ and $3.67-5.00$ respectively. There was a moderate level of agreement towards river development based on the overall mean score recorded (3.61). Comparatively, majority of the respondents (61.3\%) were recorded to had a moderate agreement towards river development, $38.4 \%$ had a high level of agreement towards river development, while only $0.3 \%$ of the respondents have a low level of agreement towards river development Table 5.

Differences in agreement towards river development: An independent sample t-test was employed to test differences in agreement towards river development. As depicted in Table 6 there was no significant difference in agreement towards river development between male ( $\mathrm{M}$ $=3.63, \mathrm{SD}=0.473)$ and female $(\mathrm{M}=3.56, \mathrm{SD}=0.428 ; \mathrm{t}$ $(300)=1.232, p=0.219)$. The mean differences was too small as reflected by affect size $(\mathrm{d}=0.152)$ which was considered trivial (Table 6).

Another comparison on difference in agreement towards river development was done on level of education. Level of education was recorded into three categories, namely (1) primary school and lower, (2) PMR and (3) SPM and above. The third category comprised of those who had SPM/SPMV, Skill certificate, STPM/Diploma and degree/master/PhD. 
Am. J. Environ. Sci., 7 (4): 362-369, 2011

Table 7: Difference in agreement towards river development for selected independent variables using ANOVA

\begin{tabular}{llllll}
\hline Level of education & $\mathrm{n}$ & Mean & SD & $\mathrm{F}$ & $\mathrm{p}$ \\
\hline & & & & 2.029 & 0.133 \\
Primary school or lower & 123 & 3.57 & 0.425 & & \\
PMR & 77 & 3.70 & 0.499 & & \\
SPM and above & 100 & 3.60 & 0.464 & & \\
\hline
\end{tabular}

Table 8: Relationship between agreement towards river development and selected independent variables

\begin{tabular}{lcl}
\hline Variables & $\mathrm{r}$ & $\mathrm{p}$ \\
\hline Income per month & 0.002 & 0.971 \\
Number of family members & 0.004 & 0.943 \\
Age & -0.006 & 0.920 \\
Distance to the Muar River & -0.016 & 0.781 \\
Period of staying in the areas & -0.027 & 0.644 \\
Distance to the nearest city & -0.084 & 0.146 \\
\hline
\end{tabular}

Consistent to gender, there was no significant differences in agreement towards river development among the three categories; $\mathrm{F}(2,297)=2.029, \mathrm{p}>0.05$. The mean difference among the three groups was relatively small, ranging from 3.57-3.60.

Analysis done proved that the highest mean score on agreement towards river development was recorded by respondents in the category of PMR level of education $(M=3.69)$, followed by $>$ SPM level of education $(\mathrm{M}=3.60)$ and category of <primary school $(\mathrm{M}=3.57)$. Based on $\mathrm{F}$ value $(3,300)=1.814$, $\mathrm{p}>0.005$, there was no significance different that occurred between the three groups studied (Table 7).

To investigate any relationship that might occur between selected independent variables and agreement towards river development, Pearson product-moment correlation was performed. For this purpose, a total of six independent variables have been selected namely (1) income per month; (2) number of family members; (3) age; (4) distance to the Muar River; (5) period of staying in the areas and (6) distance to the nearest city. Based on the data presented in Table 8, it can be concluded that two of the independent variables namely income per month and number of family members have a significant and positive relationship with agreement towards river development, three of the independent variables namely age, distance to the Muar River and period of staying in the areas were recorded to have a significant and negative relationship with agreement towards river development. One of the independent variable namely distance to the nearest city was found not to have any significant relationship with agreement towards river development. The magnitude of 0.971 , $0.943,0.920$ and 0.781 for income per month, number of family members, age and distance to the Muar River respectively have shown that these variables have a strong relationship with agreement towards river
development.Meanwhile, the magnitude of 0.644 for period of staying in the areas has proven that this variable has a moderate relationship with agreement towards river development.

\section{DISCUSSION}

Results gained have proven that Muar River community level of relationship with Muar River is different according to their needs. Analysis done have revealed that only a minority of Muar River community still have a strong relationship with Muar River in term of fulfilling their basic needs and as their sources of income. A number of reasons can explain why this is happening. First, adequate water supply for the Muar River community are causing them not to depend on Muar River for activities such as taking bath, washing and as a water supply for their farming and animal rearing activities. As for the sources of income, it hugely depends on the level of pollution at Muar River. As the commodity plantation such as palm oil is rapidly developed along the Muar River, it brings negative impacts such as pollution which bring threats to the economic activities such as fish and prawn fishing, boat renting, fish and river prawn cage rearing. Consequently, all of these will negatively affect the income of the Muar River community. Furthermore, some of the areas at Muar have been developed as the industrial areas; giving a lot of choices for job selection for the Muar River community. As for the recreational activities, it seems that Muar River community still use the Muar River for activities such as fish and prawn fishing. However, only a minority of the Muar River community still use Muar River spend leisure time with their family, picnic and kayaking/canoeing.

Even though only a minority of Muar River community still depends on the Muar River for their socio-economic activities, a large majority of them have a moderate and high level of agreement towards Muar River development. A large majority of them agree if the Muar River can be developed it can promote local development growth, enhance economic activities, benefit Muar River community, provide alternative transportation, strengthen family ties and enhance Muar River community awareness towards the importance of Muar River. More importantly, the Muar River community does believe that Muar River development has a huge potential to reduce the flood risk, natural disaster that still haunted the Muar River community.

Further analysis done have proven that factor of income per month, number of family members, age, distance to the Muar River and period of staying in the areas have a significant relationship with the agreement 
towards river development. As for the factors of income per month and family members, it indicates that the higher income of the Muar River community and the larger their family, the higher their level of agreement towards Muar River development and this is not surprising as it is in line with a number of previous studies. Higher income community is always related to the success of the rural development program brought by the government to an area (Lin, 2010; Othman and Sirbadhoo, 2009). Rural community who received the positive impacts of such development will result in higher level of agreement towards development among them. For factor of age, distance to Muar River and period of staying in the areas it indicates that the older the Muar River community, the farthest they stay from Muar River and the longer they stay in the areas, the lower their level of agreement towards the development of Muar River and this is in line with a number of previous studies. Senior or older people are always related to their reluctant to accept development and Palaciosa (2005) claimed that older people are reluctant to accept new invention or development as this group are highly associated with the traditional way of life while (Rosdahl and Kowalski, 2008) in the other hand has supported the result of this study when they stressed that older people may not agree with the potential and benefits of the river development as this group are having difficulties in adjusting to change. Jenstsch and Shucksmith (2004), in the other study claimed that when it comes to the support of development (for example, the rural development), is highly associated with young people and not to the older people. Distance to the river has something to do with agreement towards river development as the World Bank (2009) has proven that factor of distance have influence on the development. However, in this study it can be concluded that distance to the nearest city doesn't has any significant relationship with agreement towards development, thus it contradicts with previous findings proved by the World Bank (2009) where they claimed that increasing distance and time travelling from the city is related to the reduce in agreement towards development and productivity.

Based on this findings it is recommended that facilities for recreational activities can be developed and added which will enable more recreational activities such as fish and river prawn fishing, picnic and kayaking/canoeing to be conducted along Muar River. Furthermore, a number of national and international events can be conducted at the Muar River with the focus of the events can be on fish and prawn fishing. Doubtlessly, of these activities have the potential to flourish the economic activities of the Muar
River community. Campaigns that focus on the development of the Muar River and river pollution can be conducted to enhance consciousness and awareness among the local community and those who categorized as older, stay far away from Muar River and senior villagers can be included as the target groups of the campaign.

\section{CONCLUSION}

Based on the analysis done, it can be concluded that Muar River still has something to offer to the Muar River community. Only a minority of Muar River community still have a strong relationship to the Muar River in term of basic and daily needs and as the sources of income. However, a large number of Muar River community still depend on Muar River for their recreational activities such as fishing and netting. Overall, Muar River community has a moderate level of agreement towards river development. To ensure the relevance of Muar River to the Muar River community, it is recommended that facilities for recreational activities can be developed and added, a number of national and international events can be conducted at the Muar River and Campaigns that focus on the development of the Muar River and river pollution can be conducted.

\section{REFERENCES}

Bahaman, A.S., J.L. D'Silva, H.A.M. Shaffril and J. Uli, 2010. Attitude towards contract farming among malaysian agriculture learning institution students. Am. J. Econ. Bus. Admin., 2: 266-271. DOI: 10.3844/ajebasp.2010.266.271

Hassan, M.S., H.A.M. Shaffril, B.A. Samah, M.S.S. Ali and N.S. Ramli, 2010. Producing television agriculture program: Issues and problems among Malaysian television producers. J. Soc. Sci., 6: 356-360. DOI: 10.3844 /jssp.2010.356.360

Hossain, M.B., T. Sakai and M.Z. Hossain, 2011. River embankment and bank failure: A study on geotechnical characteristics and stability analysis. Am. J. Environ. Sci., 7: 102-107. DOI: 10.3844/ajessp.2011.102.107

Jenstsch, B. and M. Shucksmith, 2004. Young People in Rural Areas of Europe. 1st Edn., Ashgate Publishing Ltd., Aldershot, ISBN: 9780754634782 , pp: 334.

Lin, T., 2010. Toward harmonious countryside: Rural development survey results of the people's Republic of China. ADB Economics Working Paper Series. McCartan, M. and C. Brady, 2007. Middletown to Monaghan 'A social economic study of the benefits of the proposed reopening of the Ulster Canal. 
Misra, P., 2007. Dredging and Integrated Development of Inland Waterways.

Nunally, J.C., 1967. Psychometric Theory. 3rd Edn., Tata McGraw-Hill Education, New York, ISBN: 9780071070881, pp: 640.

Othman, A.A.E. and N. Sirbadhoo, 2009. An innovative partnership framework for sustainable development of rural areas in South Africa: The role of project management firms. J. Eng. Design Technol., 7: 243-263. DOI: 10.1108/17260530910998677

Palaciosa, S.P.I., 2005. Farmers' attitudes towards sustainable agriculture in Japan. J. Jap. Stud., 25: 187-202. DOI: $10.1080 / 10371390500226266$

Rosdahl, C.B and M.T. Kowalski, 2008. Textbook of Basic Nursing. 9th Edn., Lippincott William and Wilkins, Philadelphia, ISBN: 9780781765213 , pp: 1741.

Shaffril, H.A.M., B.A. Samah, J.L. D'Silva and J. Uli, 2011. Global warming at the east coast zone of peninsular Malaysia. Am. J. Agric. Biol. Sci., 6: 377-383. DOI: 10.3844/ajabssp.2011.377.383

Shaffril, H.A.M., J.L. D'Silva, J. Uli and B.A. Samah, 2010. Gender issue in contract farming: The case of Malaysian students. Am. J. Agricult. Bio. Sci., 5: 204-209. DOI: 10.3844/ajabssp.2010.204.209
Sudar, A., 2005. Measuring nontraditional benefits and costs of inland navigation. J. Transportation Res. Board., 1909: 47-53. DOI: 10.3141/1909-07

World Bank, 2009. World Development Report 2009: Reshaping Economic Geography. 1st Edn., World Bank Publication, Washington, D.C., ISBN: 9780821376072, pp: 383.

Yamani, M., A. Goorabi and J. Dowlati, 2011. The effect of human activities on river bank stability (case study). Am. J. Environ. Sci., 7: 244-247. DOI: 10.3844/ajessp.2011.244.247

Yassin, S.M., H.A.M. Shaffril, B.A. Samah, M.S. Hassan and M.S. Othman et al., 2011. Quality of life of rural community: A comparison between three cities. J. Soc. Sci., 7: 508-515. DOI: 10.3844/jssp.2011.508.515

Yassin, S.M., H.A.M. Shaffril, M.S. Hassan, M.S. Othman and B.A. Samah et al., 2010. Prospects of waterway development as a catalyst to improve regional and community socio-economy level. Am. J. Econ. Bus. Admin, 2: 240-246. DOI: 10.3844/ajebasp.2010.240.246 